\title{
A BRCA1 és BRCA2 gének tumorevolúcióban szerepet játszó mutációinak vizsgálata
}

\author{
Ph.D. értekezés tézisei \\ Enyedi Márton Zsolt \\ Témavezető: Dr. Haracska Lajos, D.Sc, \\ tudományos tanácsadó
}

MTA Szegedi Biológiai Kutatóközpont

Genetikai Intézet

SZTE Természettudományi és Informatikai Kar

Biológia Doktori Iskola

2017. Szeged 


\section{Bevezetés:}

A rák genetikai eredetü betegség, melynél a sejtek átalakulásáért és elburjánzásáért elsősorban a genetikai állományban végbemenő változások tehetők felelőssé. Ezt a folyamatot gyakran hasonlítják a darwini evolúciós modellhez, miszerint a sejt DNS-ében fokozatosan, lépésről-lépésre következnek be a genetikai elváltozások, melyeknek köszönhetően az érintett sejtek szelekciós előnyökre tesznek szert a környezetükben lévő többi sejtekhez képest. Az emlő- és petefészek-daganatok kialakulása során egy ilyen fontos evolúciós lépésnek tekintik a BRCA1 és BRCA2 tumorszuppresszor gének inaktiválódását. Ez azzal magyarázható, hogy a BRCA gének által kódolt fehérjéknek kulcsszerepe van a genomstabilitás megőrzésében, melyet több szerepük révén is biztosítanak. Ezek közül a legfontosabb a homológ rekombinációban való részvételük, ami a DNS-kettős szálú törések hibamentes kijavításának fontos útvonala.

A BRCA génekhez köthető tumorigenezisnek megkülönböztetjük örökletes és sporadikus változatát. Örökletes BRCA tumorevolúcióról abban az esetben beszélünk, ha az egyik BRCA allél csíravonal-mutációt hordoz, míg a másik allél helyileg, a tumorban inaktiválódik a tumorképződés egy későbbi szakaszában. Ezzel szemben sporadikus BRCA tumorigenezis során mindkét allél szomatikus úton inaktiválódik. Az örökletes BRCA mutációk előfordulási aránya emlő- és/vagy petefészek-daganatok esetében 10-20\%, míg a szomatikus mutációk gyakorisága 5-10\% között változik. Tekintettel arra, hogy egy örökletes BRCA mutáció akár 90\%-kal is megnövelheti a tumor kialakulásának kockázatát, továbbá, hogy mind szomatikus mind örökletes BRCA mutáns ovárium daganatok esetében lehetőség van nagy hatékonyságú, személyre szabott tumorterápia alkalmazására, a mutációk időben történő azonosításának kiemelt egészségügyi jelentősége van. 
A BRCA1-2 gének mutációinak szürésére már az 1990-es évek elején történt felfedezésük után nagy igény mutatkozott. Az évek során különböző módszerek váltották egymást, melyek közül a legmegbízhatóbbnak a Sanger szekvenálást tartják. Mivel a BRCA gének viszonylag nagyméretüek és a bennük előforduló mutációk a génen belül bárhol lehetnek, a Sanger szekvenálás igencsak költséges és időigényes diagnosztikai eljárást eredményez. Az asztali méretű újgenerációs szekvenáló platformok elterjedésével azonban lehetőség nyílt arra, hogy a BRCA1-2 mutáció-detektálási folyamatokat ezekre a berendezésekre helyezzük át, megnövelve ezáltal a módszer áteresztőképességét és érzékenységét, ami lehetővé teszi a mutációk tumormintából történő azonosítását akkor is, ha a mintában lévő tumorsejtek aránya alacsony. Mindez elsődleges fontosságú ahhoz, hogy a BRCA tumorigenezis folyamatát megismerjük, illetve annak kimenetelét befolyásolni tudjuk. A többféle eredetű biológiai minta és mutációtípus, továbbá a célzott terápiák megjelenése a BRCA1-2 esetében egy olyan új diagnosztikai eljárás kidolgozását teszi szükségessé, amely képes magába integrálni az igények sokaságát, megbízható módszert nyújtva az örökletes és sporadikus BRCA mutációk kimutatására. 


\section{Célkitüzések:}

Doktori munkám során egy olyan komplex BRCA diagnosztikai eljárás kidolgozását tűztem ki célul, amely a gének multiplex PCR alapú amplifikálását, újgenerációs szekvenálását és a kimenő adatok bioinformatikai elemzését integrálja annak érdekében, hogy megbízható módszert nyújtson az örökletes és sporadikus BRCA inaktiválódás kimutatására. Ezt a kutatási és fejlesztési folyamatot az alábbi lépésekben terveztem kivitelezni:

1. Hatékony eljárás kidolgozása a BRCA1 és BRCA2 gének genomi DNS-mintából történő dúsítására, és újgenerációs szekvenálásra alkalmas DNS-fragmentkönyvtár készítés optimalizálása.

2. Hozzájárulni egy, az újgenerációs szekvenálások kiértékeléséhez használható bioinformatikai programcsomag kifejlesztéséhez. Az adatelemzés és mutáció-analízis tesztelése kóroki BRCA mutációt hordozó kontroll mintákon.

3. A kidolgozott munkafolyamat validálása Ion Torrent PGM és Illumina MiSeq újgenerációs szekvenáló platformokon. A két platform összehasonlítása BRCA mutációdetektálás szempontjából.

4. A kidolgozott diagnosztikai módszer tesztelése tumormintákon. A BRCA tumorevolúció folyamatának vizsgálata ovárium tumorokban. 


\section{Alkalmazott módszerek:}

A BRCA1 és BRCA2 gének genomból történő amplifikálását multiplex PCR reakciók segítségével oldottam meg. Az ehhez szükséges primereket a Primer3 és a Clone Manager szoftver segítségével terveztem.

A multiplex PCR termékeket restrikciós enzimekkel emésztettem, majd platformspecifikus adaptereket ligáltam hozzájuk. Az így kapott fragmentkönyvtárakat fragment analízissel ellenőriztem, qPCR segítségével kvantitáltam és Ion Torrent PGM, illetve Illumina MiSeq újgenerációs szekvenáló platformokon szekvenáltam.

A mintaelőkészítés lépéseinek optimalizálásával párhuzamosan egy újgenerációs szekvenálás-adatelemző szoftver fejlesztésében is részt vettem. Az NGSeXplorer az általános adatelemzési lépések mellett (szétválogatás, illesztés, variánskeresés, stb.) olyan algoritmusokat is tartalmaz, amelyek kifejezetten az Ion Torrent szekvenálási kémiából adódó hibák kiküszöbölését szolgálják.

A mutációk azonosítására kidolgozott munkafolyamatot a Coriell mintabankból származó, BRCA csíravonal mutációt hordozó sejtvonalakon teszteltem, majd egy független mintacsoporton validáltam, összehasonlítva az Ion Torrent PGM és az Illumina MiSeq platformokon kapott szekvenálási eredményeket és mutációs mintázatot.

A részleges vagy teljes géndeléciók és duplikációk kimutatására dózishányadost számoltam az újgenerációs szekvenálás lefedettségi adataiból. Az így kapott eredményeket MLPA analízissel validáltam.

A csíravonal mutációkon validált diagnosztikai módszert tumormintákon is teszteltem. Elöször egy tízfős, petefészek daganatos betegcsoport esetében vizsgáltam a BRCA mutációs 
státuszt párhuzamosan a csíravonalban és a tumormintában. Ezt követően egy olyan, 25 betegből álló csoportot is megvizsgáltam, ahol csak ovárium tumorminta állt rendelkezésre a mutáció-analízis elvégzésére. Az azonosított mutációkat minden esetben Sanger szekvenálással validáltam.

\section{Eredmények és megvitatásuk:}

1. A BRCA diagnosztikai eljárás kidolgozása során két mintacsoportot használtam (teszt és validációs csoport). Mindkét csoport olyan mintákat tartalmazott, amelyek valamilyen örökletes mutációt hordoznak a $B R C A 1$ vagy a $B R C A 2$ génben. A tesztcsoportba tartozó 24 mintát használtam a mintaelőkészítés lépéseinek optimalizálására, valamint az NGSeXplorer paramétereinek beállítására, különös tekintettel az Ion Torrent szekvenálási hibák kiküszöbölésére szolgáló szürő-algoritmusok finomhangolására. A mintaelőkészítés és adatelemzés optimalizálásának köszönhetően sikerült a szekvenálások során a megfelelő lefedettségi értékeket elérni, a variánselemzés pedig helyesen azonosította a mutációkat mind a 24 minta esetében.

2. Ezután következett a kidolgozott diagnosztikai eljárás validálása. A húsz mintából álló validációs csoport szintén BRCA1 vagy BRCA2 mutáns mintákból állt, de ezúttal a mutációk pontos helye és szekvenciája a validálást végző személy előtt ismeretlen volt. A DNS-mintákból készített fragmentkönyvtárakat Illumina MiSeq és Ion Torrent PGM platformokon is megszekvenáltam, összehasonlítva a molekuláris diagnosztikában jelenleg leggyakrabban használt két szekvenáló berendezésen kapott eredményeket. Az összehasonlításból kiderült, hogy az Illumina MiSeq helyesen azonosította a kóroki mutációt mind a 20 mintában, fals pozitív találat nélkül. Az Ion Torrent esetében a variáns-szürő 
algoritmusok ugyan segítettek megszabadulni a fals pozitív találatok 97,3\%-ától, azonban egy esetben a valódi mutációt is szekvenálási hibának minősítették, ami a diagnosztikai érzékenység csökkenését eredményezte (95\%).

3. A BRCA1 és BRCA2 gének átfogó diagnosztikai folyamatának alkalmasnak kell lennie a két gént érintő nagyobb átrendeződések detektálására is. Ezért teszteltem az általam fejlesztett módszer alkalmasságát exon deléciók és duplikációk kimutatására. Erre e célra két tesztminta állt rendelkezésre, amelyekben megfelelően sikerült azonosítani az MLPA módszerrel előzőleg kimutatott átrendeződéseket.

4. A kifejlesztett BRCA diagnosztikai módszert olyan DNS-mintákon is teszteltem, amelyeket ovárium tumorokból izoláltak. Az elsőként megvizsgált tíz betegmintából négyben azonosítottunk mutációt, amelyek közül három örökletes volt, egy pedig sporadikus. Ez utóbbi egy új BRCA1 mutáció volt (c.628C>T; p. Q210*), melyet eddig még egyetlen adatbázisban sem regisztráltak. Ugyanakkor ebben a mintában sikerült nyomon követni a sporadikus BRCA tumorevolúció egyes lépéseit is, melyek során az egyik BRCA1 allél a fent említett mutáció révén inaktiválódott, a másik pedig nagy átrendeződés során veszett el (LOH, loss of heterozygosity).

5. Ezt követően újabb 25 ováriumtumor-minta $B R C A$ mutációs státuszát vizsgáltam meg. A minták közel felében sikerült azonosítani olyan BRCA1 vagy BRCA2 mutációt, amely a daganatképződéssel összefüggésbe hozható. Ezeknek a mutációknak a nagy része örökletes volt, kettőről azonban feltételezhetjük, hogy csak a daganatban volt jelen. A mutáns allél aránya az esetek többségében homozigóta irányba tolódott el, ami arra utal, hogy a vad típusú allél ezekben a tumorokban is LOH által inaktiválódott. Mindez felhívja a figyelmet annak fontosságára, hogy a diagnosztikai folyamat során a BRCA gének mutációs státuszát a csíravonal mellett a tumormintában is megvizsgáljuk. 


\section{Összefoglalás:}

Összegzésképpen elmondható, hogy a tumorevolúcióban szerepet játszó BRCA mutációk vizsgálatára kifejlesztettünk egy olyan diagnosztikai folyamatot, amelyet csíravonal és tumor DNS-mintákon is sikeresen teszteltünk és mutációk széles spektrumára nézve validáltunk Ion Torrent PGM és Illumina MiSeq újgenerációs szekvenáló platformon egyaránt. A módszerrel a pontmutációk és kisebb inszerciók/deléciók mellett a teljes exonokat érintő deléciókat és dulpikációkat is azonosítani tudtuk. Az általunk megvizsgált ovárium daganatok közel felében azonosítottunk olyan BRCA mutációkat, amelyek valamilyen formában hozzájárulhattak a daganat kialakulásához. A legtöbb BRCA mutáns daganat esetében a BRCA1 vagy a BRCA2 gén egyik allélja örökletes mutáció révén inaktiválódott, míg a másik allél a tumorevolúció későbbi szakaszában szomatikus esemény révén veszett el. Találkoztunk azonban olyan esettel is, amikor mindkét BRCA allél szomatikus mutáció/esemény által inaktiválódott a daganatsejtekben. Az általunk kifejlesztett módszer tehát alkalmas a BRCA tumorevolúció egyes lépéseinek nyomonkövetésére tumormintákban, Illumina szekvenáló platform használata mellett pedig teljesíti a diagnosztikai módszerek pontosságára és megbízhatóságára vonatkozó klinikai elvárásokat is. 


\section{Publikációk:}

\section{A doktori eljárás alapját képező 2 db közlemény:}

Enyedi MZ, Jaksa G, Pintér L, Sükösd F, Gyuris Z, Hajdu A, Határvölgyi E, Priskin K, Haracska L. Simultaneous detection of BRCA mutations and large genomic rearrangements in germline DNA and FFPE tumor samples. Oncotarget. 2016. doi: 10.18632/oncotarget, IF (2014): 6,35

E. Ruprecht, M. Z. Enyedi, A. Szabó, A. Fenesi.: Biomass removal by clipping and raking vs burning for the restoration of abandoned Stipa-dominated European steppe-like grassland. Applied Vegetation Science. 2015. DOI: 10.1111/avsc.12199. IF (2015): 2,30

\section{MTMT azonosító: 10051399}

Összes IF: 23,442

\section{Referált folyóiratban megjelent közlemények:}

\subsection{A disszertáció témájához kapcsolódó közlemény:}

Enyedi MZ, Jaksa G, Pintér L, Sükösd F, Gyuris Z, Hajdu A, Határvölgyi E, Priskin K, Haracska L. Simultaneous detection of BRCA mutations and large genomic rearrangements in germline DNA and FFPE tumor samples. Oncotarget. 2016. doi: 10.18632/oncotarget, IF (2014): 6,35

\subsection{Egyéb közlemények:}

Mórocz M, Zsigmond E, Tóth R, Enyedi MZ, Pintér L, Haracska L. DNA-dependent protease activity of human Spartan facilitates replication of DNA-protein crosslinkcontaining DNA. Nucleic Acids Res. 2017; gkw1315. doi: 10.1093/nar/gkw1315. IF (20152016): 9,202

E. Ruprecht, M. Z. Enyedi, A. Szabó, A. Fenesi.: Biomass removal by clipping and raking vs burning for the restoration of abandoned Stipa-dominated European steppe-like grassland. Applied Vegetation Science. 2015. DOI: 10.1111/avsc.12199. IF (2015): 2,30

E. Ruprecht, M. Z. Enyedi, R. L. Eckstein, T. W. Donath: Restorative removal of plant litter and vegetation 40 years after abandonment enhances re-emergence of steppe grassland vegetation. Biological Conservation. 2010. 143: 449-456. IF (2010): 4,29 
E. Ruprecht, A. Szabó, M. Z. Enyedi \& J. Dengler: Steppe-like grasslands in Transylvania (Romania): characterization and influence of management on species diversity and composition. Tuexenia. 2009. 29: 353-368.

Enyedi, M.-Zs., Ruprecht, E. \& Deák, M: Long-term effects of the abandonment of grazing on steppe-like grasslands. Applied Vegetation Science. 2008. 11: 53-60. IF (2008): 1,30

\section{Egyéb szakmai anyagok:}

\section{Kéziratok:}

Cs. Brasko, K. Smith, Cs. Molnar, L. Hegedus, A. Balind, N. Farago, L. Paavolainen, T. Balassa, A. Szkalisity, F. Sukosd, B. Balint, M. Z. Enyedi, I. Nagy, L. G. Puskas, L. Haracska, G. Tamas, \& P. Horvath. Intelligent image-based in situ single-cell isolation. Beküldve.

\section{Konferencia részvételek:}

Sükösd F, Enyedi M, Hajdu A, Pankotai-Bodó G, Gyuris Z, Jaksa G, Pintér L, Haracska L. Ovárium karcinómák és örökletes emlörákok BRCA mutáció vizsgálata. EME, Orvos-és Gyógyszerésztudományi Szakosztály, XXVI. Tudományos Ülésszak, Marosvásárhely (RO), 2016.

Enyedi M., Jaksa G., Pintér L., Gyuris Z., Keresztné Határvölgyi E., Priskin K., Haracska L.: A BRCA1 és BRCA2 gének diagnosztikája új generációs szekvenálással. EME, Orvos-és Gyógyszerésztudományi Szakosztály, XXV. Tudományos Ülésszak, Kolozsvár (RO), 2015.

P. Sarkozy, Enyedi M, P. Antal: Flow Index Based Characterization of Next Generation Sequencing Errors, 5th International Conference on Bioinformatics Models, Methods and Algorithms (Biostec), 2014.

Enyedi M-Zs. Szegedi Biológus Doktorandusz Konferencia: A BRCA1 és BRCA2 tumor szuppresszorok mutációinak és interakcióinak jellemzése a DNS-hibatolerancia útvonalban. Szekció előadói díj. 2013.

Enyedi M., Gyuris Z., Keresztné Határvölgyi E., Haracska L: Az újgenerációs szekvenálás alkalmazási lehetőségei a molekuláris tumordiagnosztikában. EME, Orvos-és Gyógyszerésztudományi Szakosztály, XXIII. Tudományos Ülésszak, Székelyudvarhely (RO), 2013.

M. Enyedi, Z. Gyuris, E. Határvölgyi, A. Hajdu, Sz. Bakó, F. Sükösd, L. Haracska: Mutational analysis of oncogenes along the EGFR signal transduction pathway. 3rd International Congress and 29th Annual Scientific Session of Romanian Society for Cell Biology, Arad (RO). 2011. 
Enyedi, M.-Zs., Ruprecht, E., Józsa, J: Kísérleti beavatkozások hatása felhagyott szárazgyepek fajainak csírázási dinamikájára. VIII. Kolozsvári Biológus Napok. 2007.

Enyedi, M.-Zs.: Árvalányhajas sztyepprétek átalakulása felhagyásuk következtében az Erdélyi Mezőségen. Aktuális forra és vegetációkutatás a Kárpá t-medencében VII. Debrecen. 2006.

Enyedi, M.-Zs: Az Erdélyi Mezőség árvalányhajas sztyepprétjeinek előfordulását meghatározó tényezők. VI. Kolozsvári Biológus Napok.2005. 